\title{
Gene Therapy Approaches to Prevent Corneal Graft Rejection: Where Do We Stand?
}

\author{
Thomas Ritter Mieszko Wilk Mikhail Nosov \\ College of Medicine, Nursing and Health Sciences, School of Medicine, Regenerative Medicine Institute, \\ National University of Ireland, Galway, Ireland
}

\section{Key Words}

Cornea · Transplantation · Gene therapy · Costimulation .

Inhibitory receptor $\cdot$ Immunomodulation $\cdot$ Eye disease it will be discussed why the development of clinical trials for the genetic modification of corneal grafts prior to transplantation is lagging behind of those for the treatment of inherited retinal diseases.

Copyright $\odot 2013$ S. Karger AG, Basel

\begin{abstract}
Cornea transplantation (penetrating keratoplasty) is the most frequently performed transplant procedure in humans. Despite advances in microsurgery and immunosuppressive treatment protocols, a significant number of corneal grafts still undergo immune-mediated allograft rejection. Topical treatment with corticosteroids is currently the gold standard and while this treatment is effective in many corneal transplant patients, it is much less effective in 'highrisk' patients with previous episodes of neovascularisation or graft rejection. Therefore, alternative approaches such as genetic modification of donor corneas are needed to prevent corneal transplant rejection. Cornea transplantation holds the unique advantage in that gene therapy can be used to modify allografts ex vivo prior to transplantation. Many preclinical studies using local (and systemic) gene transfer have been performed to date and many different gene transfer vehicles (gene therapy vectors) and therapeutic strategies (immunomodulatory or graft-protective) have been investigated to prevent corneal allograft rejection. The most recent gene therapy applications to prevent corneal allograft rejection will be reviewed in this article. Moreover,
\end{abstract}

\section{Introduction}

Cornea transplantation (penetrating keratoplasty) is the most often performed transplant procedure in humans. Failure of corneal transplants is often not considered significant in the absence of risk factors. This can usually be explained by the immune privilege of the avascular cornea, which is grafted to an immune-privileged site, the anterior chamber of the eye. However, this immune privilege is not robust as it can be overcome and graft rejection is not uncommon. Reports on the incidence of graft rejection after penetrating keratoplasty vary between 5 and $40 \%$ [1]. With regard to long-term observations, the 5-year prognosis for penetrating keratoplasty is even inferior to solid organ transplantation and estimated to be approximately $50 \%$ [2]. Topical treatment with corticosteroids is currently the gold standard in corneal transplantation in patients [3]. While this treatment is effective in many patients, it is much less effective in 'high-risk' patients with previous episodes of

\section{KARGER}

E-Mail karger@karger.com

www.karger.com/ore
(C) 2013 S. Karger AG, Basel

0030-3747/13/0503-0135\$38.00/0
Thomas Ritter, $\mathrm{PhD}$

College of Medicine, Nursing and Health Sciences

School of Medicine, Regenerative Medicine Institute (REMEDI)

National University of Ireland, Galway (Ireland)

E-Mail thomas.ritter@ nuigalway.ie 
Table 1. Summary of recent gene therapeutic applications to prevent corneal graft rejection

\begin{tabular}{|c|c|c|c|c|c|c|c|}
\hline Vector & Treatment & $\begin{array}{l}\text { Therapeutic } \\
\text { gene }\end{array}$ & Promoter & Function/effect & $\begin{array}{l}\text { Animal } \\
\text { model }\end{array}$ & Results & Ref. \\
\hline Adenovirus & $\begin{array}{l}\text { Ex vivo and systemic } \\
\text { gene transfer }\end{array}$ & $\begin{array}{l}\text { ICOSIg } \\
\text { fusion gene }\end{array}$ & CMV & $\begin{array}{l}\text { Inhibition of costimulation by blocking the } \\
\text { interaction between ICOS and ICOS-L }\end{array}$ & Rat & $\begin{array}{l}\text { No prolongation of } \\
\text { graft survival }\end{array}$ & [31] \\
\hline Lentivirus & Ex vivo gene transfer & PD-L1 & Ubiquitin & $\begin{array}{l}\text { Modulates graft infiltrating cells expressing } \\
\text { PD-1 }\end{array}$ & Rat & $\begin{array}{l}\text { Significantly prolongs } \\
\text { allograft survival }\end{array}$ & [40] \\
\hline Lentivirus & Ex vivo gene transfer & $\begin{array}{l}\text { Ovine } \\
\text { IL-10 }\end{array}$ & SV40 & $\begin{array}{l}\text { Inhibits Th1 immune response, down- } \\
\text { regulates APC activity }\end{array}$ & Sheep & $\begin{array}{l}\text { Moderate prolongation } \\
\text { of graft survival }\end{array}$ & [45] \\
\hline Adenovirus & $\begin{array}{l}\text { Ex vivo and systemic } \\
\text { gene transfer }\end{array}$ & vIL-10 & CMV & $\begin{array}{l}\text { Inhibits Th1 immune response, down- } \\
\text { regulates APC activity }\end{array}$ & Rat & $\begin{array}{l}\text { Only systemic expression } \\
\text { leads to prolongation of } \\
\text { graft survival }\end{array}$ & [44] \\
\hline $\begin{array}{l}\text { Plasmid/ } \\
\text { liposomes }\end{array}$ & Ex vivo gene transfer & vIL-10 & CMV & $\begin{array}{l}\text { Inhibits Th1 immune response, } \\
\text { ownregulates APC activity }\end{array}$ & Rat & $\begin{array}{l}\text { Only marginal prolonga- } \\
\text { tion of graft survival }\end{array}$ & [44] \\
\hline Adenovirus & $\begin{array}{l}\text { Ex vivo gene transfer } \\
\text { and systemic expression }\end{array}$ & IL-12p40 & CMV & $\begin{array}{l}\text { Modulates IL-12 function by its natural } \\
\text { inhibitor IL-12p } 40\end{array}$ & Rat & $\begin{array}{l}\text { No prolongation of graft } \\
\text { survival }\end{array}$ & [47] \\
\hline
\end{tabular}

IL-12p40 = Interleukin-12 p40 subunit; Th1 = T helper 1; Th2 = T helper 2; IL-10 = interleukin-10; vIL-10 = Epstein Barr Virus derived IL-10; APC = antigen-presenting cell; ICOSIg = inducible costimulator-immunoglobulin; ICOS-L = inducible costimulator-ligand.

neovascularisation or graft rejection [4]. Systemic immunosuppression has reduced the rejection rate of corneal allografts; however, prolonged use of these agents can produce significant side effects that may limit their use in a non-life-threatening indication. Therefore, alternative approaches are needed to prevent corneal transplant rejection such as genetic modification of donor corneas.

\section{Genetic Modification of Corneal Allografts prior to Transplantation}

Cornea transplantation is unique in that gene therapy can be used to modify allografts ex vivo prior to transplantation. In contrast to other tissues that are routinely transplanted, the cornea can be kept in culture for up to 4 weeks without significant loss of function which allows sufficient time for ex vivo manipulation. However, it has also been reported that endothelial cell loss during storage is mediated by apoptosis which may contribute to early graft loss after transplantation $[5,6]$. Local expression of therapeutic genes may be sufficient to achieve a therapeutic effect thus making systemic (genetic) intervention either unnecessary or required only at reduced doses thereby avoiding undesired side effects. In this article, the most recent gene therapy applications to prevent immune-mediated corneal allograft rejection will be briefly summarised (table 1). Genetic modification of corneal tissues with the view of improving endothelial viability during storage has been published recently $[7,8]$. However, gene therapy for endothelial protection or for treatment of corneal diseases has been reviewed recently and will not be discussed in this review $[9,10]$.

The majority of preclinical gene-therapeutic studies to improve organ graft survival including corneal grafts utilise recombinant viral vectors derived from adenoviruses (Ad), lentiviruses (LV) or adeno-associated viruses (AAV) as gene transfer vehicles [11-13]. Non-viral gene transfer would avoid many issues concerning unwanted immune responses against the viral vector and/or the therapeutic gene and also with regard to general safety aspects such as reversion to potentially pathogenic wild-type virus. The efficiency of gene transfer into corneal cells, however, is reportedly low [13]. In contrast, viral vectors are generally characterized by their high transduction efficiency of different cell types and tissues, although transduction efficiency may vary, depending on the cell type. Ad vectors predominantly transduce the corneal endothelium, whereas the epithelium and stroma are refractive to Ad-mediated gene transfer [14-17]. Due to the genetic DNA backbone of the Ad vector used in many studies, Ad-transduced cells will still express adenoviral proteins. These antigens can be presented via major histocompatibility complex molecules on endothelial cells or keratocytes and stimulate 
T-cell-mediated immunity. This may result in short-term, transient expression of the therapeutic gene which might be sufficient or even desired in certain circumstances when long-term expression of the therapeutic gene might not be beneficial. Unlike Ad, AAV and LV vectors are generally considered as gene therapy vehicles leading to long-term gene expression in target cells due to their low immunogenic profile and their integration into the cellular genome [18]. Although integration does not seem to lead to pathological consequences when using AAV vectors, cellular integration of lentiviral vectors in chromosomal areas harbouring tumour genes has led to insertional mutagenesis and tumour formation [19]. LV vectors used for gene therapy in cornea transplantation are either derived from primate LV (HIV or SIV) or from non-primate LV (equine infectious anaemia virus) by removing most of the viral genes and regulatory elements and have been shown to efficiently transduce corneal endothelium and keratocytes [20-22]. AAV vectors have recently attracted much attention as gene therapy vehicles in clinical trials for the treatment of inherited retinal diseases, e.g. Leber's congenital amaurosis [23]; however, its value as an efficient vector for corneal gene therapy is controversially discussed in the literature. While it has been described that AAV shows no or little efficiency in transducing corneal cells [24], other groups report successful AAV gene therapy using novel pseudotyping strategies [25]. These results may be explained in part by the fact that more than 10 serotypes are currently described for AAV which use different surface receptors for cell entry.

\section{Gene-Therapeutic Applications to Prevent Corneal Allograft Rejection}

Several different experimental approaches have been investigated in recent years to promote corneal allograft survival which include ex vivo viral and non-viral gene transfer in cultured corneas, intrastromal vector injection, systemic gene transfer pre- and post-corneal transplant and tolerogenic approaches. Similar gene therapeutic strategies are currently being investigated in the related field of solid organ transplantation. While some of these strategies such as systemic gene transfer have been proven successful in preclinical models but are unlikely to be transferred into a clinical scenario in non-life-threatening disease (side effects of systemic application, difficulty to control), we will be focussing in this article mainly on reviewing ex vivo gene transfer approaches as a safer method for using viral vectors.

Gene Therapy Approaches to Prevent

Corneal Graft Rejection

\section{Costimulatory Blockade and Inhibitory Receptor}

Expression

The immune system and in particular allo-activated $\mathrm{T}$ cells play a central role during corneal allograft rejection. Many studies indicate that rejection of corneal allografts is mediated predominantly by CD4+ T lymphocytes [26, 27]. In order to become fully activated, T cells need to engage via the $\mathrm{T}$ cell receptor with major histocompatibility complex class I or II molecules (signal 1) and costimulatory molecules present on antigen-presenting cells which can either transmit positive or negative signals into $\mathrm{T}$ cells (signal 2) [28]. Interfering with the CD28-B7.1(CD80)/B7.2(CD86) pathway has been shown to be important in inhibiting $\mathrm{T}$ cell activation and preventing graft rejection [11]. Modulation of other costimulatory pathways has also been studied for their potential to prevent corneal allograft rejection with various degrees of success. ICOS (Inducible Costimulator) is an inducible costimulatory receptor expressed by activated $\mathrm{T}$ cells and memory $\mathrm{T}$ cells [29]. Blocking the interaction of ICOS with its receptor has been shown to be an effective strategy to prevent autoimmune disease [30] or allogeneic graft rejection; however, the timing of treatment seems to be critical. We have analysed the effect of Ad-mediated overexpression of soluble ICOSIg (AdICOSIg) and neither local nor systemic administration of AdICOSIg prolonged corneal graft survival [31]. This may indicate that the inhibition of primary immune responses is more important in order to prolong corneal graft survival than inhibiting memory cells by ICOSIg.

Recently the PD-1/PD-L1 pathway has been shown to play a role in the negative regulation of immune responses (fig. 1) [32, 33]. Programmed cell death (PD) ligand 1 (PD-L1) and programmed cell death ligand 2 (PD-L2) are known ligands for PD-1. PD-L1 has been detected on lymphoid cells including monocytes, antigen-presenting cells and B cells, as well as in non-lymphoid tissues such as the heart, lung, placenta, kidney, liver and cornea [3437]. It has been documented that blockage of either PD-1 or PD-L1 using antibodies leads to accelerated graft rejection in mouse corneal allograft models [38]. Furthermore, systemic application of a soluble PD-L1-Ig fusion protein was able to prolong allogeneic graft survival in a mouse corneal transplant model [39] highlighting the importance of this pathway. We showed that LV-mediated overexpression of PD-L1 in cultured corneas significantly prevents corneal graft rejection by modulating graftinfiltrating cells [40]. This striking result was associated with a reduction of natural killer $\mathrm{T}$ cells and cytotoxic CD8+ T cell infiltration, and was also accompanied by at- 


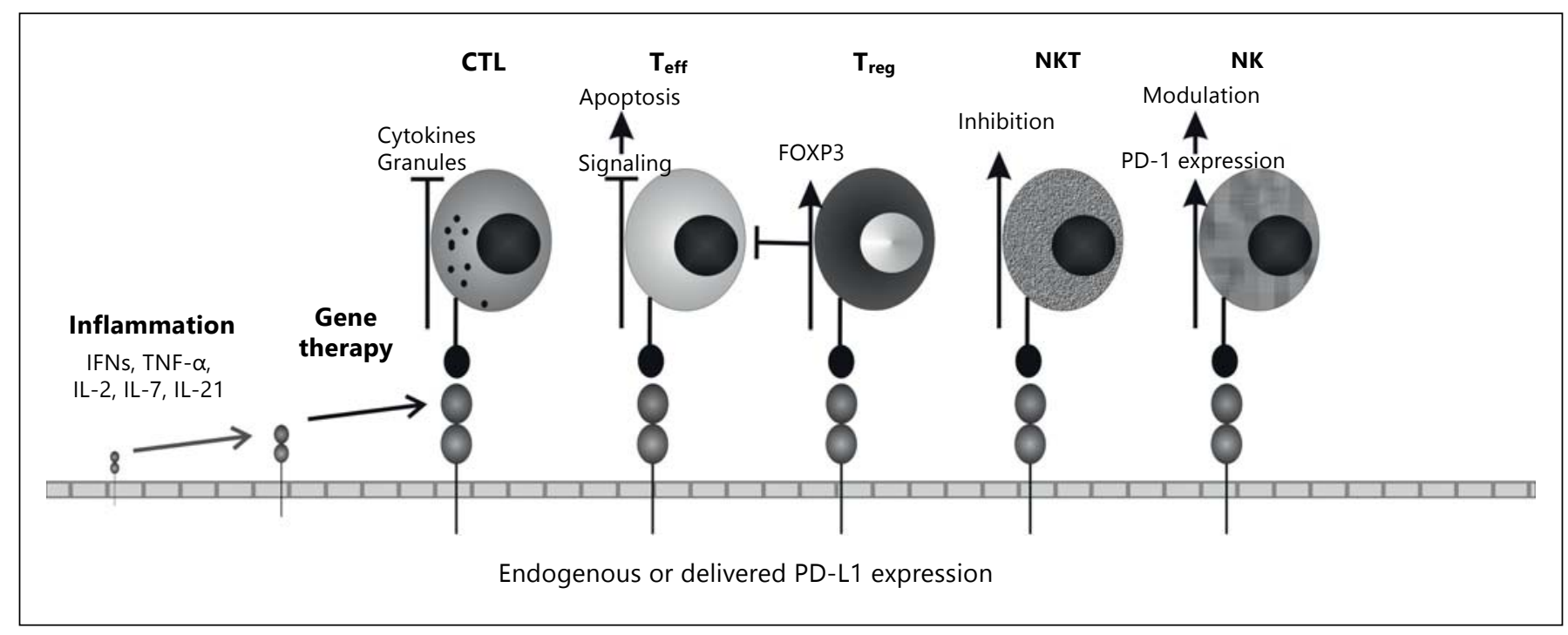

Fig. 1. Possible mechanisms of PD-L1-mediated immunomodulation. Figure 1 illustrates how inflammation or gene-therapeutic intervention leads to an increase in PD-L1 protein on the surface of corneal endothelial cells. Interaction of cytokine-induced or gene-engineered PD-L1 with various infiltrating immune cell populations may lead to an inhibition of cytotoxic T cells (CTL), en- hance programmed cell death (apoptosis) in effector T cells $\left(\mathrm{T}_{\text {eff }}\right)$ or lead to an increase in the number of regulatory $\mathrm{T}$ cells $\left(\mathrm{T}_{\text {reg }}\right) . \mathrm{T}_{\text {reg }}$ cells may also inhibit $\mathrm{T}_{\text {eff }}$ cells. Inhibition of natural killer $\mathrm{T}$ (NKT) or modulation of NK cells may also be promoted by forced or cytokine-induced PD-L1 expression. tenuation of pro-inflammatory cytokine expression [40]. Interestingly, the neovascularisation of transplanted corneas seemed to be unaffected by this therapy.

\section{Overexpression of Immunomodulatory Cytokines and} Growth Factors

Interleukin (IL)-10, and its Epstein-Barr virus-encoded IL-10 homologue viral IL-10 (vIL-10), is probably the most studied cytokine due to its potent immunomodulatory properties such as diminishing the antigen-presenting capacity of monocytes and inhibition of monokine production such as IL-1, IL-6, IL-8, and TNF- $\alpha[41,42]$. It is well documented that gene transfer of IL-10 leads to prolonged graft survival in different transplant models including the cornea $[14,43]$. It has been shown that Admediated IL-10 gene transfer in cultured corneas leads to significant prolongation of graft survival in an outbred sheep corneal transplant model [14]. Subsequent studies investigated both non-viral (liposomes) and viral (Ad) genetic modification of cultured corneas in a high-responder major histocompatibility complex class I/II mismatched rat transplant model. Although neither strategy led to prolongation of corneal graft survival, systemic administration of AdvIL-10 in transplant recipients significantly prolonged allograft survival [44]. Recently, Parker et al. [45] investigated LV-mediated gene transfer of ovine IL-10 in cultured corneas in the sheep transplant model. LVovineIL-10 gene transfer was less efficient in prolonging corneal graft survival compared to Ad-mediated gene transfer. LVovineIL-10 gene transfer seems to be less efficient in producing IL-10 compared to AdvIL-10 although a different promoter was used in this study (SV40 vs. CMV in the previous study), which makes the results difficult to compare. Overall, IL-10 gene transfer seems to be beneficial but it will need further research to fully evaluate the potential of IL-10 gene therapy in cornea transplantation. Besides IL-10 gene transfer, inhibition of the pro-inflammatory cytokine IL-12 by overexpression of the IL-12p40 inhibitory subunit has also been investigated in different animal models of cornea transplantation and also showed varying results $[46,47]$.

A number of neurotropic growth factors and their associated receptors have been found in the anterior segment of the eye. Among these nerve growth factor (NGF), neurotrophin-3 and -4 and their receptors are present in the cornea [48]. It has been reported that NGF is able to modulate an immune response from a predominantly Th1 type to a Th2 type $[49,50]$. Moreover, it has been described recently that NGF is present in the anterior segment of the eye and plays an important role in tissue main- 
tenance and wound healing [51]. Overexpression of AdNGF in ex vivo cultured corneas significantly prolonged corneal allograft survival in a rat transplant model [52]. Interestingly, costimulatory blockade (by CTLA4Ig co-administration even at 10 -fold reduced doses compared to CTLA4Ig therapy alone) could substantially prolong corneal allograft survival indicating that local growth factor gene therapy may require additional immunosuppression in order to achieve extended graft survival [52].

\section{Conclusions and Future Outlook}

Although multiple successful gene-therapeutic strategies to prevent corneal allograft rejection have been investigated, to the best of our knowledge no clinical trials have emerged from these studies. This is somewhat surprising because ex vivo gene transfer in cultured corneas allows local tissue manipulation in a culture dish followed by removal of excessive gene transfer vehicles before transplantation thereby reducing viral exposure of the graft recipient. Moreover, the risk of insertional mutagenesis as it happened when integrating gene therapy vectors used to modify hematopoietic stem cells might be lower if differentiated cells were the target cells [53]. This may further support corneal gene therapy using LV vectors as corneal buttons may contain few stem cells only. In addition, rapid development of improved vectors with reduced potential for induction of chromosomal aberrations should help to move corneal gene therapy towards clinical trials [18]. A key problem in further developing gene therapy in organ transplantation seems to be the multitude of suitable genes which could be successfully applied to prolong graft survival. This is in contrast to the recent successful gene therapy clinical trials for retinal diseases in which single gene defects are targeted [54]. Currently it is not clear which therapeutic gene should best be used for gene therapy in cornea transplantation. Gene transfer of secreted molecules such as immunomodulatory cytokines seems to be able to produce good results; however, it is not clear how these secreted molecules might affect neighbouring cells in the eye after transplantation. In this context, expression of membrane-bound therapeutic molecules such as PD-L1 might have an advantage as these will only interact with infiltrating immune cells but not with other cell types thereby reducing the risk of unwanted or unexpected side effects. As it emerges from currently available data, a gene-therapeutic strategy focusing on local (corneal) manipulation combining immunomodulatory/anti-inflammatory with anti-apoptotic gene transfer to prevent endothelial cell loss could be the most promising gene therapy approach for a clinical trial to prevent corneal allograft rejection in the near future.

\section{Acknowledgements}

The authors have no financial interest related to the manuscript. The authors would like to thank Dr. Kieran Ryan for critically reading the manuscript. The work presented in this review was in part supported by Science Foundation of Ireland (SFI PI Award 07/IN.1/B925 and 09/SRC/B1794) and European Union Structural Funds.

\section{References}

$>1$ Pleyer U, Schlickeiser S: The taming of the shrew? The immunology of corneal transplantation. Acta Ophthalmol 2009;87:488497.

-2 Williams KA, Esterman AJ, Bartlett C, Holland $\mathrm{H}$, Hornsby NB, Coster DJ: How effective is penetrating corneal transplantation? Factors influencing long-term outcome in multivariate analysis. Transplantation 2006; 81:896-901.

$\checkmark 3$ Price FW Jr, Price DA, Ngakeng V, Price MO: Survey of steroid usage patterns during and after low-risk penetrating keratoplasty. Cornea 2009;28:865-870.

$\checkmark 4$ O'Doherty M, Murphy CC: Update on immunosuppressive therapy for corneal transplantation. Int Ophthalmol Clin 2010;50:113-122.

$>5$ Gain P, Thuret G, Chiquet C, Dumollard JM, Mosnier JF, Burillon C, Delbosc B, Herve P, Campos L: Value of two mortality assessment techniques for organ cultured corneal endothelium: trypan blue versus TUNEL technique. Br J Ophthalmol 2002;86:306-310.

-6 Bourges JL, Valamanesh F, Torriglia A, Jeanny JC, Savoldelli M, Renard G, BenEzra D, de Kozak Y, Behar-Cohen F: Cornea graft endothelial cells undergo apoptosis by way of an alternate (caspase-independent) pathway. Transplantation 2004;78:316-323.

$>7$ Fuchsluger TA, Jurkunas U, Kazlauskas A, Dana R: Corneal endothelial cells are protected from apoptosis by gene therapy. Hum Gene Ther 2011;22:549-558.

$>8$ Fuchsluger TA, Jurkunas U, Kazlauskas A, Dana R: Anti-apoptotic gene therapy prolongs survival of corneal endothelial cells during storage. Gene Ther 2011;18:778-787.

$\checkmark 9$ Mohan RR, Tovey JC, Sharma A, Tandon A: Gene therapy in the cornea: 2005-present. Prog Retin Eye Res 2012;31:43-64.
10 Williams KA, Klebe S: Gene therapy for corneal dystrophies and disease, where are we? Curr Opin Ophthalmol 2012;23:276-279.

11 Ritter T, Pleyer U: Novel gene therapeutic strategies for the induction of tolerance in cornea transplantation. Expert Rev Clin Immunol 2009;5:749-764.

-12 Parker DG, Brereton HM, Coster DJ, Williams KA: The potential of viral vector-mediated gene transfer to prolong corneal allograft survival. Curr Gene Ther 2009;9: 33-44.

13 Kampik D, Ali RR, Larkin DF: Experimental gene transfer to the corneal endothelium. Exp Eye Res 2012;95:54-59.

14 Klebe S, Sykes PJ, Coster DJ, Krishnan R, Williams KA: Prolongation of sheep corneal allograft survival by ex vivo transfer of the gene encoding interleukin-10. Transplantation 2001;71:1214-1220.
Gene Therapy Approaches to Prevent

Corneal Graft Rejection
Ophthalmic Res 2013;50:135-140 DOI: $10.1159 / 000350547$ 
15 Larkin DF, Oral HB, Ring CJ, Lemoine NR, George AJ: Adenovirus-mediated gene delivery to the corneal endothelium. Transplantation 1996;61:363-370.

16 Ritter T, Vogt K, Rieck P, Schilling-Schon A, Kolls J, Hartmann C, Volk HD, Pleyer U: Adenovirus-mediated gene transfer of interleukin-4 to corneal endothelial cells and organ cultured corneas leads to high IL-4 expression. Exp Eye Res 1999;69:563-568.

17 Qian Y, Leong FL, Kazlauskas A, Dana MR: Ex vivo adenovirus-mediated gene transfer to corneal graft endothelial cells in mice. Invest Ophthalmol Vis Sci 2004;45:2187-2193.

18 Balaggan KS, Ali RR: Ocular gene delivery using lentiviral vectors. Gene Ther 2012;19:145153.

19 Fischer A, Hacein-Bey-Abina S, CavazzanaCalvo M: Gene therapy for primary adaptive immune deficiencies. J Allergy Clin Immunol 2011;127:1356-1359.

20 Wang X, Appukuttan B, Ott S, Patel R, Irvine J, Song J, Park JH, Smith R, Stout JT: Efficient and sustained transgene expression in human corneal cells mediated by a lentiviral vector. Gene Ther 2000;7:196-200.

-21 Beutelspacher SC, Ardjomand N, Tan PH, Patton GS, Larkin DF, George AJ, McClure MO: Comparison of HIV-1 and EIAV-based lentiviral vectors in corneal transduction. Exp Eye Res 2005;80:787-794.

-22 Parker DG, Kaufmann C, Brereton HM, Anson DS, Francis-Staite L, Jessup CF, Marshall K, Tan C, Koldej R, Coster DJ, Williams KA: Lentivirus-mediated gene transfer to the rat, ovine and human cornea. Gene Ther 2007;14:760-767.

23 Ali RR: Ocular gene therapy: introduction to the special issue. Gene Ther 2012;19:119-120.

-24 Hudde T, Rayner SA, De Alwis M, Thrasher AJ, Smith J, Coffin RS, George AJ, Larkin DF: Adeno-associated and herpes simplex viruses as vectors for gene transfer to the corneal endothelium. Cornea 2000;19:369-373.

25 Sharma A, Tovey JC, Ghosh A, Mohan RR: AAV serotype influences gene transfer in corneal stroma in vivo. Exp Eye Res 2010;91:440448.

-26 Pleyer U, Milani JK, Dukes A, Chou J, Lutz S, Ruckert D, Thiel HJ, Mondino BJ: Effect of topically applied anti-CD4 monoclonal antibodies on orthotopic corneal allografts in a rat model. Invest Ophthalmol Vis Sci 1995;36:52-61.

27 He YG, Ross J, Niederkorn JY: Promotion of murine orthotopic corneal allograft survival by systemic administration of anti-CD4 monoclonal antibody. Invest Ophthalmol Vis Sci 1991;32:2723-2728.

28 McGrath MM, Najafian N: The role of coinhibitory signaling pathways in transplantation and tolerance. Front Immunol 2012; 3:47.

29 Hutloff A, Dittrich AM, Beier KC, Eljaschewitsch B, Kraft R, Anagnostopoulos I, Kroczek RA: ICOS is an inducible T-cell costimulator structurally and functionally related to CD28. Nature 1999;397:263-266.
30 Rottman JB, Smith T, Tonra JR, Ganley K, Bloom T, Silva R, Pierce B, Gutierrez-Ramos JC, Ozkaynak E, Coyle AJ: The costimulatory molecule ICOS plays an important role in the immunopathogenesis of EAE. Nat Immunol 2001;2:605-611.

31 Fabian D, Gong N, Vogt K, Volk HD, Pleyer $\mathrm{U}$, Ritter T: The influence of inducible costimulator fusion protein (ICOSIg) gene transfer on corneal allograft survival. Graefes Arch Clin Exp Ophthalmol 2007;245:1515-1521.

32 Nishimura H, Nose M, Hiai H, Minato N, Honjo T: Development of lupus-like autoimmune diseases by disruption of the PD-1 gene encoding an ITIM motif-carrying immunoreceptor. Immunity 1999;11:141-151.

33 Nishimura H, Honjo T: PD-1: an inhibitory immunoreceptor involved in peripheral tolerance. Trends Immunol 2001;22:265-268.

34 Dong H, Zhu G, Tamada K, Chen L: B7-H1, a third member of the B7 family, co-stimulates T-cell proliferation and interleukin-10 secretion. Nat Med 1999;5:1365-1369.

35 Latchman Y, Wood CR, Chernova T, Chaudhary D, Borde M, Chernova I, Iwai Y, Long AJ, Brown JA, Nunes R, Greenfield EA, Bourque K, Boussiotis VA, Carter LL, Carreno BM, Malenkovich N, Nishimura $H$, Okazaki T, Honjo T, Sharpe AH, Freeman GJ: PD-L2 is a second ligand for PD-1 and inhibits $\mathrm{T}$ cell activation. Nat Immunol 2001;2:261-268.

36 Yamazaki T, Akiba H, Iwai H, Matsuda H, Aoki M, Tanno Y, Shin T, Tsuchiya H, Pardoll DM, Okumura K, Azuma M, Yagita H: Expression of programmed death 1 ligands by murine T cells and APC. J Immunol 2002;169:55385545.

37 Ishida M, Iwai Y, Tanaka Y, Okazaki T, Freeman GJ, Minato N, Honjo T: Differential expression of $\mathrm{PD}-\mathrm{L} 1$ and $\mathrm{PD}-\mathrm{L} 2$, ligands for an inhibitory receptor PD-1, in the cells of lymphohematopoietic tissues. Immunol Lett 2002; 84:57-62.

38 Hori J, Wang M, Miyashita M, Tanemoto K, Takahashi H, Takemori T, Okumura K, Yagita H, Azuma M: B7-H1-induced apoptosis as a mechanism of immune privilege of corneal allografts. J Immunol 2006;177:5928-5935.

39 Watson MP, George AJ, Larkin DF: Differential effects of costimulatory pathway modulation on corneal allograft survival. Invest Ophthalmol Vis Sci 2006;47:3417-3422.

40 Nosov M, Wilk M, Morcos M, Cregg M, O'Flynn L, Treacy O, Ritter T: Role of lentivirus-mediated overexpression of programmed death-ligand 1 on corneal allograft survival. Am J Transplant 2012;12:1313-1322.

41 de Waal Malefyt R, Haanen J, Spits H, Roncarolo MG, te Velde A, Figdor C, Johnson K, Kastelein R, Yssel H, de Vries JE: Interleukin 10 (IL-10) and viral IL-10 strongly reduce antigen-specific human $\mathrm{T}$ cell proliferation by diminishing the antigen-presenting capacity of monocytes via downregulation of class II major histocompatibility complex expression. J Exp Med 1991;174:915-924.
42 de Waal Malefyt R, Abrams J, Bennett B, Figdor CG, de Vries JE: Interleukin 10 (IL-10) inhibits cytokine synthesis by human monocytes: an autoregulatory role of IL-10 produced by monocytes. J Exp Med 1991;174: 1209-1220.

43 Qin L, Ding Y, Pahud DR, Robson ND, Shaked A, Bromberg JS: Adenovirus-mediated gene transfer of viral interleukin- 10 inhibits the immune response to both alloantigen and adenoviral antigen. Hum Gene Ther 1997;8:13651374.

44 Gong N, Pleyer U, Volk HD, Ritter T: Effects of local and systemic viral interleukin-10 gene transfer on corneal allograft survival. Gene Ther 2007;14:484-490.

45 Parker DG, Coster DJ, Brereton HM, Hart $\mathrm{PH}$, Koldej R, Anson DS, Williams KA: Lentivirus-mediated gene transfer of interleukin 10 to the ovine and human cornea. Clin Experiment Ophthalmol 2010;38:405-413.

46 Klebe S, Coster DJ, Sykes PJ, Swinburne S, Hallsworth P, Scheerlinck JP, Krishnan R, Williams KA: Prolongation of sheep corneal allograft survival by transfer of the gene encoding ovine IL-12-p40 but not IL-4 to donor corneal endothelium. J Immunol 2005; 175:2219-2226.

47 Ritter T, Yang J, Dannowski H, Vogt K, Volk $\mathrm{HD}$, Pleyer U: Effects of interleukin-12p40 gene transfer on rat corneal allograft survival. Transpl Immunol 2007;18:101-107.

48 You L, Kruse FE, Volcker HE: Neurotrophic factors in the human cornea. Invest Ophthalmol Vis Sci 2000;41:692-702.

49 Ramer-Quinn DS, Baker RA, Sanders VM Activated $\mathrm{T}$ helper 1 and $\mathrm{T}$ helper 2 cells differentially express the beta-2-adrenergic receptor: a mechanism for selective modulation of T helper 1 cell cytokine production. J Immunol 1997;159:4857-4867.

50 Sanders VM, Baker RA, Ramer-Quinn DS, Kasprowicz DJ, Fuchs BA, Street NE: Differential expression of the beta2-adrenergic receptor by Th1 and Th2 clones: implications for cytokine production and B cell help. J Immunol 1997;158:4200-4210.

51 Klenkler B, Sheardown H: Growth factors in the anterior segment: role in tissue maintenance, wound healing and ocular pathology. Exp Eye Res 2004;79:677-688.

52 Gong N, Pleyer U, Vogt K, Anegon I, Flugel A, Volk HD, Ritter T: Local overexpression of nerve growth factor in rat corneal transplants improves allograft survival. Invest Ophthalmol Vis Sci 2007;48:1043-1052.

53 Bartholomae CC, Arens A, Balaggan KS, Yanez-Munoz RJ, Montini E, Howe SJ, Paruzynski A, Korn B, Appelt JU, Macneil A, Cesana D, Abel U, Glimm H, Naldini L, Ali RR, Thrasher AJ, von Kalle C, Schmidt M: Lentiviral vector integration profiles differ in rodent postmitotic tissues. Mol Ther 2011;19: 703-710.

54 Ali RR: Gene therapy for retinal dystrophies: twenty years in the making. Hum Gene Ther 2012;23:337-339. 